\title{
HIGHER EDUCATION IN THE FIELD OF REGIONAL DEVELOPMENT - E-LEARNING AND TRAINING FIRM APPROACHES
}

DOI: https://doi.org/10.18509/GBP210557k

UDC: 378.018.43:004]:331.1.055.2(497.2)

\author{
Nikolay Katsarski \\ Sofia University „St. Kliment Ohridski“, Faculty of Geology and Geography, Department \\ "Regional Development", Sofia, Bulgaria
}

\begin{abstract}
Higher education is important for economic growth especially for the rapid development of regions. Using different approaches in the education process develops skills that can be used in both science and practical moments. Compelling both of these methods of study is the key for regional growth for economically developing counties like Bulgaria. The scientific approach of study is not useful for that moment of economic development. The reason is hidden in low investment opportunities in innovations for small and medium-sized enterprises and scarce of free cash. That is why businesses want from universities graduated students with practical experience. Often this requirement is impossible because of the specific business activities and additional teaching is needed. In that case, the dual approach will be the best opportunity. This approach includes a practical aspect of the science and simulation it with real operations. Students in the field of regional development must have complex knowledge in the area of economic, social, politics, and geography. These areas of study help for future regional economic growth. Now the pandemic situation in the world put higher education in online mode. The universities moved to e-learning platforms like Moodle, Teams, Zoom, etc. The main problem is related to a few obstacles. First, most of the universities did not use the full functions of that platforms. Second, most of the teachers are not learned how to use them. Third e-learning processes have weak spots - cheating, non-direct contact with the students, etc. Fourth the main challenge would be the quality of the teaching and learning.
\end{abstract}

Keywords: regional development study, e-learning, training firm, higher education

\section{INTRODUCTION}

In this pandemic situation the teaching process is faced to a new challenge. Using different teaching approaches like blended, hybrid and online learning are the only way for education. We all know that face-to-face approach is not possible at time. But It is very important because of the direct contact for the students and academics. The main question now is which teaching approach is the best for the students? This question is hard to be answered because of the few reasons. First, all of them have advantages and disadvantages. Second, some universities are neither prepared for digital era nor their academics. Third, it is hard for the students to learn digitally. That is why the mixture between the approaches may be is the best way for education. The author's opinion is that the hybrid education approach fits best to the situation. In the era of digitalization, we all understand that we use smartphones, computers, other smart devices but we are using them only for fun. Most of us do not use the full potential of these devices.

There is another problem in this digital era which is not solved in the past. It is related to the practical education. All employees want students with practical experience and strong 
analytical skills. But it is hard to be done in some reasons. First, the practical skills are specific for every single business. Second, university education helps to be formed complex knowledge which can be used in practice. The students must know where to find the information. Third, students are learned how to deal with huge amount of information for less time. All of that form a specific need. That need can be covered by forming a training firms which can learn students to those specific skills.

Almost one year without face-to-face teaching we can see some problems so far. The problems both university and school are almost the same. But in the schools system regional educational inspectorates (as a lower management structure) create the conditions for the normal functioning of the system (organize the training, provide teachers, provide control and regulation, maintain the qualification of the teachers).[1]

\section{Learning approaches - face to face; blended learning; hybrid and online study approaches.}

In this pandemic situation the teaching process is faced to a new challenge. Using different teaching approaches is must. In this time face-to-face approach is not possible. It is very important because of the direct contact for the students and academics. Almost one year without face-to-face teaching we can see some problems so far. First, because of the age of the academics most of them did not have digital skills. Second, some students do not participate active in the lection courses and seminars. Third, educational function of the education is hard to be done fully. Fourth, students need more digital skills for education. The importance of face-to-face education is crucial for collaboration between the students and soft skills development. The EU survey including the following teaching and learning approaches:

Blended learning: A model combining face-to-face classroom teaching and the innovative use of ICT technologies. Experts often associate blended learning with the redesign of the educational environment and the learning experience, thus contributing to the creation of a "community of inquiry".[2]

Hybrid Online and face-to-face instruction are integrated, with a substantial amount of "seat time" in the traditional classroom substituted with internet-based activities.[3]

Online Nearly all instruction, interaction, and activities take place online; may or may not include a face-to-face orientation or proctored exam(s). .[4]

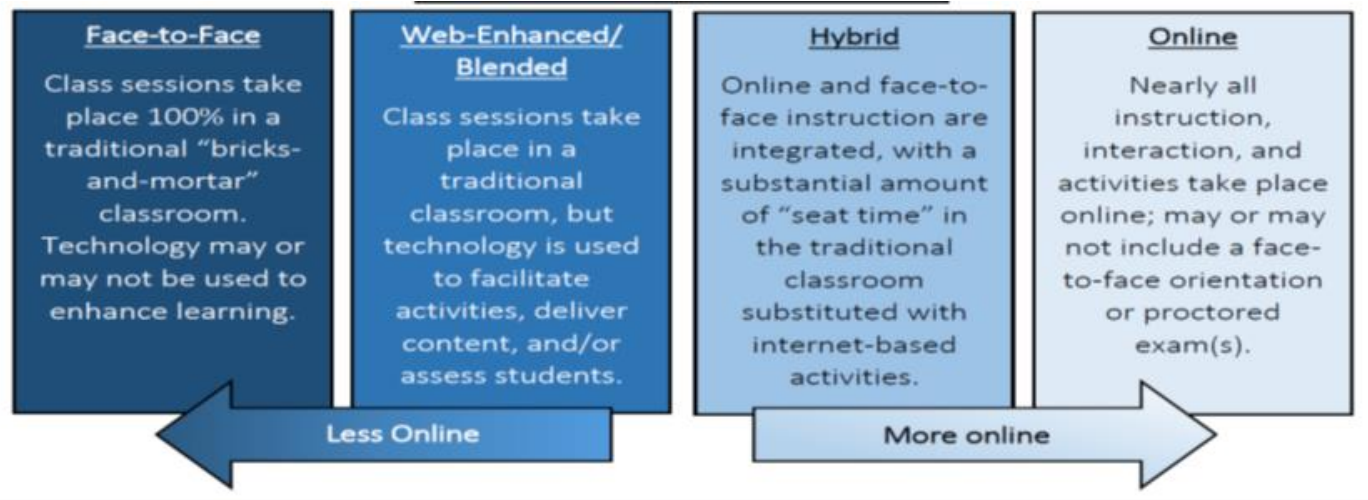

Figure 1. Online Learning Spectrum [5]

In contrast the Bulgarian situation can be presented in the following image. Image 1 . We work and study from home [6]. 


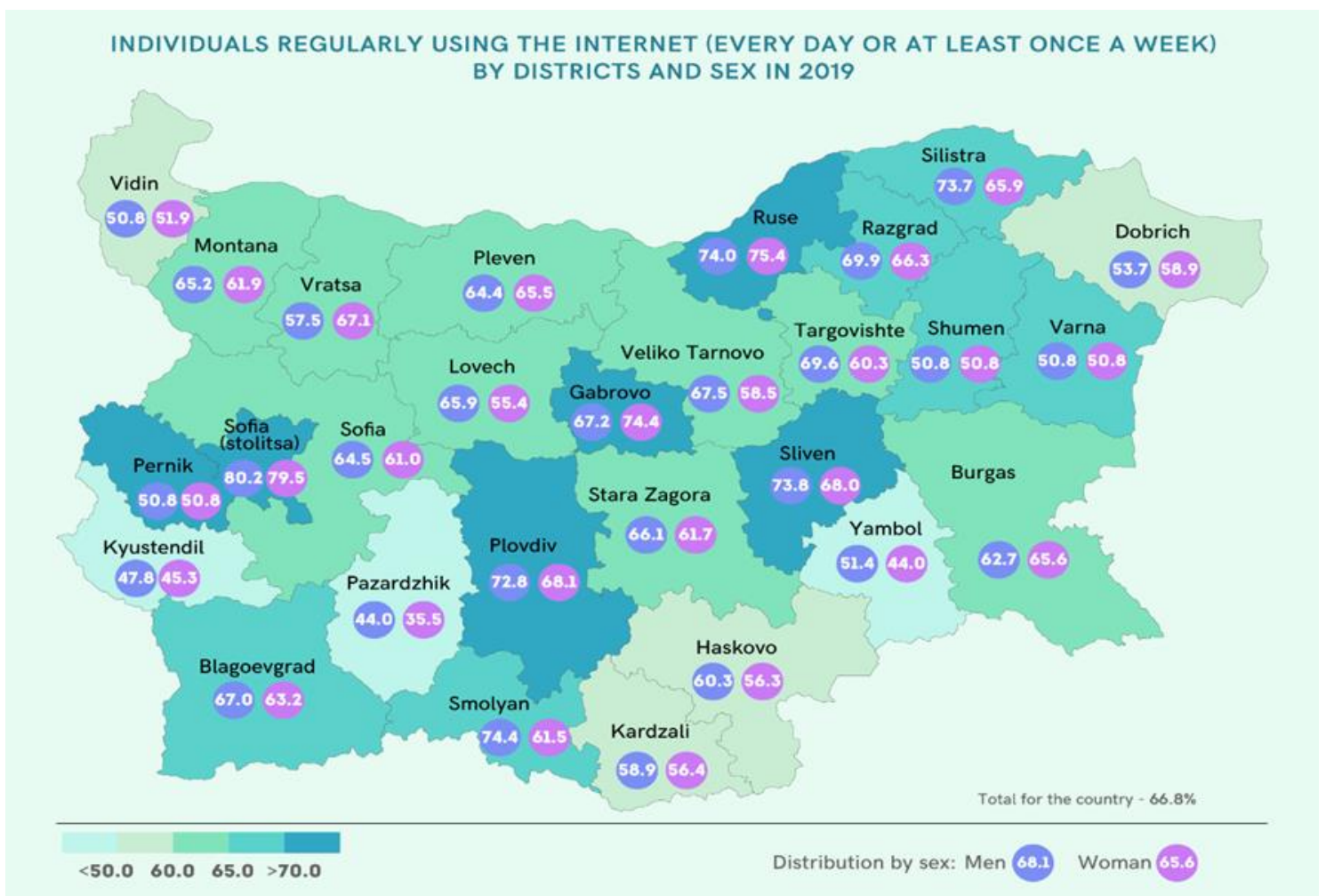

Figure 2.

The map shows disproportions for accessing the internet both education and work. It means that access to the digital platforms for some regions in Bulgaria are not the same as the others which are more developed /For example Sofia - stolitsa, Plovdiv, Ruse/. This is indicator which is showing that the students do not have the same chance to use internet for educational needs to overcome this problem some authors make relation to the economic. Reducing disparities in economic development of the different regions of Bulgaria requires a comprehensive strategy based on the principles of cohesion policy. Investments should be oriented and to the less developed regions and municipalities in order to avoid their backlog. One of the possible measures in this direction is the implementation of decentralization. With its use possible part of direct taxes to be collected and managed by local authorities, but it must function in the current levels, without additional charges. This would provide more funds for the needs of municipalities, including the implementation of programs of economic and social purpose [7].Using the mixture of teaching and learning approaches is very important. It means that students will have access $24 / 7$ for learning. It will help academics to present information more interactively.

That is why the author's opinion is that hybrid learning and teaching approach must be advanced both bachelor and master degree. In this context digital platform like Moodle is common in use for most universities in Bulgaria. Its open source helps reducing the financial costs but sometime there are crushes. Using the full potential of the platform is hard because of few reasons. First, academics are not prepared. Second, some universities did not make the platform fully functional for their needs. Third, students access to the internet in not covered. Therefore, both all academic staff and business are faced to a new problem. Another problem is related to migration as a factor that influences in the existing practice of recruiting workers from other countries [8]. 


\section{TRAINING FIRM CONCEPTION AND ITS IMPLEMENTATION IN REGIONAL DEVELOPMENT}

A training firm simulate the working process of a real firm. All the aspects of real businesses are covered. The procedures are almost the same but not in the same amount of information. Also, the activities of the raining firm cover topics like daily business communication like calls, responding to mails, working with specific software and etc. In addition, students can learn how to work in a team, how to deal with customers and purchase orders. Depends on the activities and specific area students can learn how to use the theoretical knowledge into the practice. It can help to them for taking different decisions. It means that this will make them more responsible for the others. The training firm is like a real life, we should keep in mind to common business usage and the legal framework. The difference from the real business is that in the training firm are not used real money. All the transfers and payments are made by virtual bank but with real or close to real banking transfers. The goods and services used in training firm are virtual too but the simulation works on papers. That is why every training firm should keep all the papers in accordance to the state law and requirements. The tasks used in training firm are following:

- correspondence, using new softwares in accordance of the specific activities

- dealing and responding with incoming mail;

- filing;

- using the telephone, scanner, multifunctional machine;

- working on the PC or lap top.

- designing advertising media, like for instance catalogues

- preparing power point presentation

- dealing with customers, suppliers, business partners

- purchasing and selling

- importing and exporting

- dispatch and customs clearance

- issuing invoices for purchases

- money transfers with domestic and foreign business partners

- banking operations

- entering business cases into the books

- warehouse accounting and fixed assets accounting

- calculating wages, salaries and commissions

- cost accounting

- settling the accounts with the revenue office and the national health insurance

- hosting visitors and business partners

- other mercantile tasks

These essential skills help students to be prepared for real business activities. From the viewpoint of training the practice firm allows for true-to-business practice and professional and didactic reappraisal. This simulation of the economic reality supports the trainees' creativity, self-starting qualities, entrepreneurship, responsibility, teamwork, language skills - in a nutshell, those key qualifications that are also relevant for life-long learning. And it is beyond all doubt that life-long learning is what we will depend on in the future.

The training firm is the best way to understand that this work is for you or not. This simulation to the real business helps in a few directions. First, if you take different positions in the company, you will understand which best fits to you. Second, the 
simulation to the real business is the best way for the students to understand if they like their future job or not. Third, it will give opportunity for testing new approaches and models. In the following table are summed up some differences between training business and real business.

Table. 1 Training firm VS Real Business

\begin{tabular}{|c|c|c|}
\hline \multicolumn{3}{|c|}{ Training firm VS Real Business } \\
\hline Criteria type & Training company & Real business \\
\hline Дейност Activities & $\begin{array}{l}\text { entrepreneurial decisions are made } \\
\text { as in reality, but goods and services } \\
\text { are a simulation }\end{array}$ & $\begin{array}{l}\text { the full range of possible activities, } \\
\text { goods or services }\end{array}$ \\
\hline cash flow & there is no real cash flow & real cash flow \\
\hline Entrepreneurial risk & there is no entrepreneurial risk & entrepreneurial risk \\
\hline External contacts & $\begin{array}{l}\text { primarily with other UTFs - often } \\
\text { influenced by the teacher }\end{array}$ & economic space \\
\hline $\begin{array}{l}\text { Full scope of tasks and } \\
\text { activities }\end{array}$ & $\begin{array}{l}\text { expanding the tasks and } \\
\text { responsibilities as a learning process }\end{array}$ & $\begin{array}{l}\text { The implementation of tasks, } \\
\text { activities is a necessity }\end{array}$ \\
\hline Structure & $\begin{array}{l}\text { job rotation as a central element of } \\
\text { learning }\end{array}$ & $\begin{array}{l}\text { job rotation as an element of staff } \\
\text { development in modern and } \\
\text { successful enterprises }\end{array}$ \\
\hline $\begin{array}{l}\text { Choice of branch and } \\
\text { product }\end{array}$ & \begin{tabular}{|lll} 
Teacher - student & - & training \\
companies & & \\
market & & \\
\end{tabular} & $\begin{array}{l}\text { entrepreneur, CEO or board of the } \\
\text { directors are choosing the branch and } \\
\text { niches }\end{array}$ \\
\hline Work time & 3-5 hours a week & $\begin{array}{l}\text { "Normal" working hours depending } \\
\text { on the business and law allowance }\end{array}$ \\
\hline $\begin{array}{l}\text { Successors } \\
\text { success criteria }\end{array}$ & $\begin{array}{l}\text { amount of learning opportunities, i.e. } \\
\text { the dynamics of own UTF incoming } \\
\text { mail and number of activities, testing } \\
\text { of theoritical approaches }\end{array}$ & \begin{tabular}{|lrr} 
profit, lasting & $\begin{array}{c}\text { market } \\
\text { maintaining }\end{array}$ & position \\
enterprise & and \\
workplaces, etc. & & \\
\end{tabular} \\
\hline
\end{tabular}

The main achievement and advantage for the author is to adapt these activities in the curriculum for the regional development. Other authors think that Life and practice undoubtedly have demonstrated the need for permanent improvement of teachers' training and further mastering (including geography ones), without which it is impossible to achieve the expected [9]Aspects for adaptation can be presented in the fields like:

- Regional business development.

- Regional management.

- Expertise in the field of regional development policies.

- Entrepreneurship and others.

Preparing the university curriculum in a way to respond the needs of the business and the state is always hard. The main reason is locked in between the balance in theory and practice, on one hand. On the other hand, students must have complex knowledge and can not be shaped perfect for one specific activity. That is why university can give the beginning of the carrier start with basic and specific knowledge but not full and detailed. In contrast training firm can do it. Using this teaching approach can help to be developed these specific skills which will be used in the daily work. For example, preparing students for regional business development manager position they must know:

How to approach new markets and develop it. In their responsibilities are Collaborate with key stakeholders in our business ecosystem to work on several projects and initiatives that will improve our sales efficiency; Continuously identify new opportunities and bring fresh ideas for improvement; Meet and exceed all assigned recognition targets 
and objectives. Smart technologies will be the future of the market. They will help constantly monitoring the most important infrastructure - roads, bridges, tunnels, railways, metro, airports, seaports, communication systems, water supply, power supply, even important buildings - for optimal resource allocation and safety[10]

Achieving market goals and report results. They must report on monthly and quarterly recognition and activation activities. Keep updated trackers of work progress regarding recognition, activation, scores, partnerships and other related services, ensuring these are completed and submitted in a timely manner; Report and track on other market players and activity; recognition, test centre locations etc.; Keep informed about developments within higher education and within the language testing industry.; Monitor, review, update, and analyze the different stakeholder tracker(s) and ensure all related external comms (website - list of recognizing organizations) are up to date.; Develop calendar for data collection, feedback from clients to improve our liaison and better understand/manage expectations.

Other requirements: problem-solving skills; Able to work independently; strong organizational skills.; Thrive in an agile, changing environment; Enthusiastic, high degree of integrity, self-motivated, positive attitude, proactive approach to work and a confident approach to closing business.; Excellent interpersonal and communication skills.; Able to travel overnight and frequently.

Implementing the training firm approach is always beneficial for students. They will know and understand the specific feature of the business and expertise. They will be very close to the real situation and will know how to deal with the daily professional and nonprofessional problems. Training firms can help students to be prepared for that business which pay more, satisfy the staff's needs, develop knowledge and etc. The strong demand for better training and improving of the pedagogical staff in the field of social and educational management[12] play key role for the educatoinal future. Other point of view int the future is related to smart cities. It means that new knowledge will be needed. According to urban planning goals, smart cities can be defined as "cities of knowledge", "digital cities", "cyber cities" or "eco-cities". Smart cities in economic and social terms are looking to the future. [13]

\section{CONCLUSION}

The pandemic situation brings education and business to their knees. Choosing different teaching and learning approaches depend on the specific situation. But in these conditions neither the people nor the universities were prepared. The main question is: What we have learned so far? First, the hybrid teaching and learning approaches are better than online. Second, nothing is better than face to face teaching and learning. Third, training firm approach is the only way for covering the specific practical knowledge in which must be included both academics and people from practice.

The questions for discussion so far can be summed up in: How we can fulfil the knowledge of the students after the pandemic situation? What will be the new challenges in the business and education? Should we forget some educational approaches? Last but not least Education will need to increase investment in lifelong learning to maintain productivity and an aging workforce in times of rapid technological change [14]. Moreover migration processes will affect to community-recognized socio-economic needs, legislative measures and financial incentives. [15]

\section{REFERENCES}


FROM THE SOCIAL MANAGEMENT POSITIONS. September 2018 DOI: 10.18509/GBP.2018.68 Conference: 4th INTERNATIONAL SCIENTIFIC CONFERENCE GEOBALCANICA 2018 Project: Geographical education Available from: https://www.researchgate.net/publication/327853522_GEOGRAPHY_EDUCATIONAL_SYST EM_ANALYSIS_FROM_THE_SOCIAL_MANAGEMENT_POSITIONS [accessed Apr 20 2021].

[2] Gaebel, M., Zhang, T., Stoeber, H. \& Morrisroe, A. (2021). Digitally enhanced learning and teaching in European higher education institutions. European University Association absl.

[3] Gaebel, M., Zhang, T., Stoeber, H. \& Morrisroe, A. (2021). Digitally enhanced learning and teaching in European higher education institutions. European University Association absl.

[4] Gaebel, M., Zhang, T., Stoeber, H. \& Morrisroe, A. (2021). Digitally enhanced learning and teaching in European higher education institutions. European University Association absl.

[5] An Introduction to Hybrid Teaching, Learning Technologies, 2015 https://www.codlearningtech.org/PDF/hybridteachingworkbook.pdf [accessed Feb 05 2021].

[6] We work and study from home

https://www.nsi.bg/sites/default/files/files/pages/covid/InfographicsWorkStudy_EN.png [accessed Feb 03 2021].

[7]Traykov T., Naydenov Kl. EDUCATIONAL STRUCTURE AND EMPLOYMENT OF POPULATION IN BULGARIA - GENERAL AND REGIONAL ISSUES. Available from: https://www.researchgate.net/publication/307940185_EDUCATIONAL_STRUCTURE_AND_ EMPLOYMENT_OF_POPULATION_IN_BULGARIA__GENERAL_AND_REGIONAL_ISSUES [accessed Feb 05 2021].

[8]Traykov T. Particularities of migration activities in the 21 st century. August 2017 DOI: 10.5593/sgemsocial2017/41/S15.005 Conference: Human geography; Media and communications; Information and library science; Demography and women's studies. p. 35-42, At: Albena, Bulgaria. Available from: https://www.researchgate.net/publication/330412669_Particularities_of_migration_activities_in _the_21_st_century [accessed Apr 20 2021].

[9]Vasileva M., Naydenov Kl., Kotseff G. Geography Didactics -theory and methodology (Bulgarian case December 2018 Annales Universitatis Paedagogicae Cracoviensis Studia Geographica 12:130 DOI: 10.24917/20845456.12.10 Project: Geographical education). Available from: https://www.researchgate.net/publication/332906880_Geography_Didactics_theory_and_methodology_Bulgarian_case [accessed Apr 21 2021].

[10] Naydenov Kl.,SMART CITIES - THE FUTURE OF URBAN PLANNING .August 2018 DOI: 10.5593/sgemsocial2018/5.2/S19.025 Conference: 5th SGEM International Multidisciplinary Scientific Conferences on SOCIAL SCIENCES and ARTS SGEM2018 Available from: https://www.researchgate.net/publication/329929803_SMART_CITIES__THE_FUTURE_OF_URBAN_PLANNING [accessed Apr 20 2021].

[11]Vasileva M., Naydenov Kl. GEOGRAPHY EDUCATIONAL SYSTEM ANALYSIS FROM THE SOCIAL MANAGEMENT POSITIONS. September 2018 DOI: 10.18509/GBP.2018.68 Conference: 4th INTERNATIONAL SCIENTIFIC CONFERENCE GEOBALCANICA 2018 Project: Geographical education Available from: https://www.researchgate.net/publication/327853522_GEOGRAPHY_EDUCATIONAL_SYST EM_ANALYSIS_FROM_THE_SOCIAL_MANAGEMENT_POSITIONS [accessed Apr 20 2021].

[12]Vasileva M., Naydenov Kl. GEOGRAPHY EDUCATIONAL SYSTEM ANALYSIS FROM THE SOCIAL MANAGEMENT POSITIONS. September 2018 DOI: 10.18509/GBP.2018.68 Conference: 4th INTERNATIONAL SCIENTIFIC CONFERENCE GEOBALCANICA 2018 Project: Geographical education Available from: 
https://www.researchgate.net/publication/327853522_GEOGRAPHY_EDUCATIONAL_SYST EM_ANALYSIS_FROM_THE_SOCIAL_MANAGEMENT_POSITIONS [accessed Apr 20 2021].

[13]Naydenov K1.,SMART CITIES - THE FUTURE OF URBAN PLANNING .August 2018 DOI: 10.5593/sgemsocial2018/5.2/S19.025 Conference: 5th SGEM International Multidisciplinary Scientific Conferences on SOCIAL SCIENCES and ARTS SGEM2018 Available from: https://www.researchgate.net/publication/329929803_SMART_CITIES__THE_FUTURE_OF_URBAN_PLANNING [accessed Apr 20 2021].

[14]Naydenov Kl., Ivanov M., UPRAVLENIE NA DEMOGRAFSKIA RISK V R BLGARIA TENDENCII I PERSPEKTIVI. March 2019 Conference: ГОДИШНИК НА МИННОГЕОЛОЖКИЯ УНИВЕРСИТЕТ “СВ. ИВАН РИЛСКИ”, Том 59, Св. IV, Хуманитарни и стопански науки, 2016 Project: Demography Available from: https://www.researchgate.net/publication/331833655_UPRAVLENIE_NA_DEMOGRAFSKIA _RISK_V_R_BLGARIA_-_TENDENCII_I_PERSPEKTIVI [accessed Apr 20 2021].

[15]Traykov T. Particularities of migration activities in the 21 st century. August 2017 DOI: 10.5593/sgemsocial2017/41/S15.005 Conference: Human geography; Media and communications; Information and library science; Demography and women's studies. p. 35-42, At: Albena, Bulgaria. Available from: https://www.researchgate.net/publication/330412669_Particularities_of_migration_activities_in _the_21_st_century [accessed Apr 20 2021]. 